4. Senneby A., Mejare I., Sahlin N. E., Svensäter G,. Rohlin M. Diagnostic accuracy of different caries risk assessment methods. A systematic review. J Dent. 2015. Vol. 43, issue 12. P. 1385-1393. DOI: https://doi.org/10.1016/j.jdent.2015.10.011.

5. Udod O., Voronina H. Dental caries prognosis by neural network computer technologies. EUREKA: Health Sciences. 2019. No. 6. P. 15-21. DOI: https://doi.org/10.21303/2504-5679.2019.001070

6. World Health Organization. Oral health surveys: basic methods. World Health Organization, 2013. 125 p.

DOI https://doi.org/10.30525/978-9934-26-182-4-21

\title{
БІОХІМІЧНИЙ СКЛАД РОТОВОЇ РІДИНИ ТА СИРОВАТКИ КРОВІ У ХВОРИХ НА ЦУКРОВИЙ ДІАБЕТ
}

\author{
Удод О. А. \\ доктор медичних наук, професор, \\ професор кафедри стоматології № 1 \\ Донецький національний медичний університет \\ м. Лиман, Донеиька область, Украӥна
}

Куліш А. С.

кандидат медичних наук, асистент кафедри терапевтичної стоматології та пародонтологї̈ Приватний вищий навчальний заклад «Київський медичний університет» м. Київ, Украӥна

Актуальність. Ротова рідина відіграє головну роль у підтриманні гомеостазу порожнини рота, сприяє іiі самоочищенню, нейтралізує негативний вплив кислот і лугів, має антибактеріальну і противірусну дію, забезпечує надходження мікро- та макроелементів в емаль зубів тощо [1, с. 118]. Ендокринні захворювання і порушення процесів обміну речовин в організмі певним чином позначаються на біохімічному складі ротової рідини, що в подальшому сприяє виникненню стоматологічної патології [1, с. $126 ; 2$, с. 45].

Мета дослідження - вивчити показники біохімічного складу ротової рідини та сироватки крові у хворих на цукровий діабет 1-го типу. 
Матеріали та методи. У ході дослідження у кожного з 157 обстежених хворих на цукровий діабет 1-го типу віком від 18 до 56 років зранку натщесерце (після попереднього полоскання порожнини рота дистильованою водою до чищення зубів) проводили забір нестимульованої змішаної слини в об'ємі 4 мл [3, с. 14]. Тривалість цукрового діабету 1-го типу у залучених до дослідження хворих становила від 1 до 50 років, при цьому компенсований стан діагностували у 25 хворих (14,0\% від загальної кількості), субкомпенсований стан - у 23 осіб (12,8\%), декомпенсований - у 131 пацієнта $(73,2 \%)$.

Дослідження біохімічного складу ротової рідини були виконані в лабораторії біохімії Державної установи «Національний інститут хірургії та трансплантології імені О. О. Шалімова». Перед дослідженням ротову рідину піддавали центрифугуванню протягом 20 хвилин з частотою обертання 3000 об/хв. За необхідності здійснювали додаткове центрифугування впродовж 2 хвилин з частотою обертання 10900 об/хв. Надалі у ротовій рідині колориметричним методом 3 застосуванням діагностичних наборів реагентів визначали вміст загального кальцію 3 арсеназо III, вміст магнію з ксилідиловим блакитним [3, с. 19]. Вміст неорганічного фосфору вивчали прямою реакцією з фосфомолібдатом [3, с. 21]. Дослідження проводили на автоматичному біохімічному аналізаторі. Вміст іонізованого кальцію, калію та натрію вивчали на іонселективному аналізаторі електролітів [3, с. 25]. Концентрацію фтору у ротовій рідині досліджували потенціометричним методом з використанням іонселективного електроду та універсального іонометра [4, с. 15]. Визначення біохімічного складу сироватки крові (вміст загального та іонізованого кальцію, натрію та калію, рівень глікованого гемоглобіну) проводили у клініко-діагностичній лабораторії та приватних медичних лабораторіях. Рівень глюкози в капілярній крові у хворих визначали натщесерце за допомогою глюкометра [5, с. 44]. Статистичну обробку результатів проводили за допомогою пакета ліцензійних програм SPSS Statistics 23 (IBM SPSS, CША) та MS Excel 2019.

Результати дослідження. Аналіз отриманих даних дослідження усіх 157 обстежених хворих 3 цукровим діабетом 1-го типу, в яких рівень глюкози в капілярній крові натщесерце коливався від 5,57 ммоль/л до 12,8 ммоль/л, показав, що вміст загального та іонізованого кальцію у ротовій рідині, в середньому, становив $0,36 \pm 0,02$ ммоль/л та $0,41 \pm 0,01$ ммоль/л, відповідно, це свідчить про зниження їх рівня щодо референтних значень норми. Вміст неорганічного фосфору складав 4,96 $\pm 0,15$ ммоль/л, що відповідає нормі, кальцій-фосфорний коефіцієнт при цьому був знижений відносно норми, зокрема, до $0,08 \pm 0,01$. Вміст фтору відповідав 


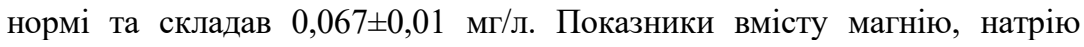
та калію у ротовій рідині, в середньому, становили, відповідно, $0,11 \pm 0,01$ ммоль/л, $17,4 \pm 0,32$ та 24,2 $\pm 0,54$ ммоль/л, що також не виходить за граничні межі.

Водночас, залежно від ступеня компенсації захворювання, біохімічний склад ротової рідини значно різнився. У хворих у стані декомпенсації вміст у ротовій рідині загального та іонізованого кальцію зі значеннями $0,31 \pm 0,02$ ммоль/л та $0,37 \pm 0,01$ ммоль/л був достовірно $(\mathrm{p}<0,05)$ нижчим у порівнянні з відповідними показниками у хворих у стані компенсації та субкомпенсації, а також з показниками фізіологічної норми. Вміст магнію був найнижчим $(\mathrm{p}<0,05)$ та складав $0,10 \pm 0,01$ ммоль/л, проте вкладався у межі норми. У цих хворих також найнижчим, але недостовірно ( $>0,05)$ був кальцій-фосфорний коефіцієнт, який дорівнював $0,07 \pm 0,01$. Вміст фтору у ротовій рідині хворих у стадії декомпенсації складав $0,067 \pm 0,001$ мг/л, тобто був у межах референтних значень норми, при цьому він не відрізнявся ( $>0,05)$ від такого в осіб у стані компенсації та субкомпенсації.

У хворих у стані компенсації цукрового діабету 1-го типу виявлено найвищий вміст у ротовій рідині загального та іонізованого кальцію зі значеннями $0,48 \pm 0,06$ ммоль/л та $0,46 \pm 0,04$ ммоль/л, визначений також найбільший кальцій-фосфорний коефіцієнт з показником $0,11 \pm 0,02$, проте ці значення були нижчими за показники норми. Вміст магнію дорівнював

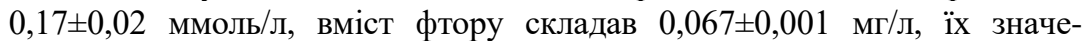
ння відповідали нормі. Разом з тим, показники вмісту неорганічного фосфору, натрію та калію у ротовій рідині хворих у стані компенсації, субкомпенсації та декомпенсації достовірно не відрізнялись $(\mathrm{p}>0,05)$ між

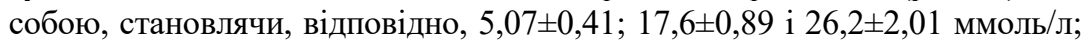
$5,31 \pm 0,0,32 ; \quad 16,7 \pm 0,84$ і $27,3 \pm 0,95$ ммоль/л; 4,92 $\pm 0,18 ; \quad 17,5 \pm 0,37$ і 23,0 0,57 ммоль/л, та не виходили за межі норми.

За результатами дослідження основних біохімічних показників сироватки крові виявлено, що за вмістом загального та іонізованого кальцію, натрію та калію вони відповідали референтним значенням показників фізіологічної норми. Так, вміст загального кальцію становив

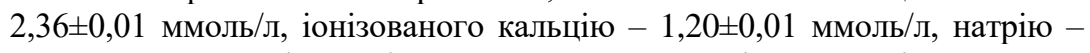

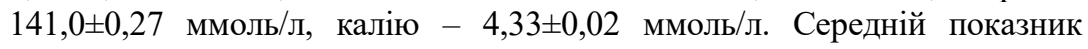
глікованого гемоглобіну дорівнював $8,72 \pm 0,16 \%$, значення глюкози в капілярній крові натщесерце складало 10,3 $\pm 0,32$ ммоль/л. У той же час, в обстежених хворих показники вмісту досліджуваних біохімічних складових сироватки крові, залежно від ступеня компенсації захворювання, достовірно між собою не відрізнялись ( $>0,05)$, на відміну від 
показників глікованого гемоглобіну та глюкози, які достовірно $(\mathrm{p}<0,05)$ відрізнялись, залежно від ступеня компенсації та мали значні індивідуальні коливання. Так, у хворих у стані компенсації показник глікованого гемоглобіну, в середньому, становив $6,52 \pm 0,09 \%$, рівень глюкози в капілярній крові був 7,03 $\pm 0,33$ ммоль/л, у стані субкомпенсації вищезазначені показники дорівнювали $7,35 \pm 0,02 \%$ та $8,14 \pm 0,52$ ммоль/л, у стані

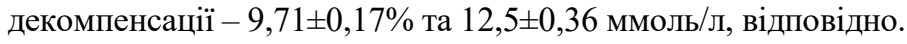

Висновки. У хворих на цукровий діабет 1-го типу встановлені значні зміни у біохімічному складі ротової рідини, зокрема, зниження вмісту загального та іонізованого кальцію, кальцій-фосфорного коефіцієнта, що найбільш проявляється у стані декомпенсації захворювання, впливає на мінералізуючі властивості ротової рідини та збільшує ризик виникнення карієсу зубів.

\section{Література:}

1. Хоменко Л. А. Детская терапевтическая стоматология. Киев: Книга-плюс; 2018. 395 с.

2. Тарасенко Л. М. Биохимия органов полости рта: учебное пособие для студентов факультета подготовки иностранных студентов. Полтава: Изд-во «Полтава»; 2008. 70 с.

3. Вавилова Т. П, Янушевич О. О., Островская И. Г. Слюна. Аналитические возможности и перспективы. Москва: Издательство Бином; 2014. 312 с.

4. Косенко К. М., Терешина Т. П., Левицький А. П. Експериментальне вивчення токсичної дії та специфічної ефективності засобів для догляду за порожниною рота (методичні рекомендації). Державний фармакологічний комітет МОЗ України. Київ; 2003. 42 с.

5. Боднар П. М. Эндокринология. Вид. 3. Вінниця: Нова Книга; 2016. $488 \mathrm{c}$. 